\title{
FAKTOR-FAKTOR YANG BERHUBUNGAN DENGAN KUALITAS TIDUR MAHASISWA YANG MENGONSUMSI KOPI DI FAKULTAS KEDOKTERAN UNIVERSITAS UDAYANA
}

\author{
Ni Kadek Novi Ardiani*, I Made Subrata \\ Program Studi Sarjana Kesehatan Masyarakat Fakultas Kedokteran Universitas Udayana
}

\begin{abstract}
ABSTRAK
Kualitas tidur merupakan gambaran yang menjelaskan tentang kemampuan seseorang mempertahankan waktu tidur dan tidak adanya gangguan yang dialami selama periode tidur. Banyak faktor dapat mempengaruhi kualitas tidur diantaranya penyakit, kondisi lingkungan seperti kebisingan dan cahaya, latihan fisik dan kelelahan, stress psikologi, obat-obatan dan zat kimia diet dan kalori, serta konsumsi kopi. Tujuan dari penelitian ini untuk mengetahui faktor-faktor yang berhubungan dengan kualitas tidur mahasiswa yang mengonsumsi kopi di Fakultas Kedokteran Universitas Udayana. Penelitian ini merupakan penelitian analitik dengan pendekatan kuantitatif menggunakan rancangan cross-sectional. Penentuan sampel pada penelitian menggunakan metode systematic random sampling dengan jumlah 118 responden. Hasil menunjukan proporsi mahasiswa dengan kualitas tidur buruk sebesar $50.85 \%$ dan kualitas tidur baik sebesar $49.15 \%$. Variabel yang secara signifikan berhubungan dengan kualitas tidur mahasiswa yaitu jenis minuman kopi (OR=2.22; 95\% $\mathrm{CI}=1.122-4.418 ; \mathrm{p}=0.022$ ) dan kelelahan psikis (OR=3.84; 95\% CI=1.509-9.777; $\mathrm{p}=0.005)$. Dapat disimpulkan terdapat hubungan antara jenis minuman kopi yang dikonsumsi mahasiswa dan faktor kelelahan psikis dengan kualitas tidur mahasiswa yang mengonsumsi kopi di Fakultas Kedokteran Universitas Udayana. Diharapkan untuk melakukan penelitian terkait dosis kafein pada jenis minuman kopi espresso, americano, cappuccino, dan latte serta meneliti faktor-faktor penyebab kelelahan psikis pada mahasiswa kedokteran yang kaitannya dengan kualitas tidur yang dialami mahasiswa.
\end{abstract}

Kata kunci: Kualitas Tidur, Konsumsi Kopi, Mahasiswa

\begin{abstract}
Sleep quality is a picture that explains about a person's ability to maintain sleep time and the absence of disturbances experienced during sleep periods. Many factors can affect sleep quality including diseases, environmental conditions such as noise and light, physical exercise and fatigue, psychological stress, drugs and chemicals, diet and calories, and coffee consumption. The purpose of this study was to determine factors related to sleep quality of students who consume coffee at the Faculty of Medicine, Udayana University. This research is an analytical study with a quantitative approach using a cross-sectional design. Determination of the sample in this study using systematic random sampling method with a total of 118 respondents. The results show the proportion of students with poor sleep quality by $50.85 \%$ and good sleep quality by $49.15 \%$. Variables that were significantly related to student sleep quality were types of coffee drinks $(\mathrm{OR}=2.22 ; 95 \% \mathrm{CI}=1,122-4,418 ; \mathrm{p}=$ $0.022)$ and psychological fatigue $(\mathrm{OR}=3.84 ; 95 \% \mathrm{CI}=1.509-9777 ; \mathrm{p}=0.005)$. It can be concluded that there is a relationship between the types of coffee drinks consumed by students and psychological fatigue factors with the sleep quality of students who consume coffee at the Faculty of Medicine, Udayana University. It is expected to conduct research related to the dose of caffeine in the types of espresso, americano, cappuccino, and latte coffee drinks and examine the factors that cause psychological fatigue in medical students related to sleep quality experienced by students.
\end{abstract}

Keywords: Sleep Quality, Coffee Consumption, Students

\section{PENDAHULUAN}

Kualitas tidur merupakan suatu keadaan yang menggambarkan tentang kemampuan seseorang untuk mempertahankan siklus tidur dan tidak terjadinya gangguan sehingga membuat seseorang tidak mengalami kantuk berlebih, sakit kepala, sering menguap, mata bengkak serta perasaan gelisah. (Christopher, Timothy, John, \& Thomas, 2013). Pola tidur yang tidak teratur dapat 
berakibat terhadap fungsi kognitif, gangguan keseimbangan fisiologi seperti penurunan aktivitas, merasakah lelah berlebih, serta penurunan daya tahan tubuh. (Sarfriyanda, Karim, \& Pristiana D, 2015).

Permasalahan periode tidur tidak hanya dialami oleh usia dewasa. Suatu penelitian epidemiologi berskala besar yang dilakukan di Eropa menunjukkan bahwa 30\% remaja berumur 15-18 tahun mengeluhkan setidaknya satu keluhan gangguan tidur. Sebesar 20\% mengalami disfungsi pada siang hari (daytime sleepiness), $12,4 \%$ mengeluh sulit untuk memulai tidur, $13,8 \%$ mengeluh tidur non restoratif serta 9,25\% mengalami kesulitan dalam mempertahankan tidur (M.Moran \& Everhart, 2012). Banyak faktor yang dapat mempengaruhi kualitas tidur diantaranya suatu penyakit, kondisi lingkungan fisik, aktivitas fisik, stress psikologi, obat-obatan dan zat kimia serta diet dan kalori (Alimul,2012). Faktor lainnya yang secara tidak langsung memengaruhi kualitas tidur seseorang yaitu mengonsumsi minuman yang mengandung kafein.

Kafein merupakan stimulan zat psikoaktif yang dipergunakan lebih dari $80 \%$ populasi di dunia (Ahmad \& Tayyab, 2017). Kafein biasanya banyak ditemukan pada minuman soda, minuman berenergi, teh, dan yang paling banyak dijumpai yaitu pada minuman kopi. Dewasa ini, penggunaan kopi tidak hanya ditemukan pada usia dewasa maupun tua. Seiring dengan munculnya gerai kopi modern, penggunaan kopi telah menjadi kebiasaan khususnya pada remaja. Menurut National
Coffee Association United States tahun 2011, terjadi peningkatan konsumsi kopi harian yaitu dari $13 \%$ menjadi $36 \%$ pada kalangan remaja dengan rentang usia 1824 tahun (Liveina, 2014).

Fakultas Kedokteran merupakan fakultas yang telah dikenal sebagai fakultas dengan beban tugas serta kegiatan perkuliahan baik akademis maupun non akademis yang padat. Ahmad \& Tayyab (2017) melakukan penelitian pada mahasiswa kedokteran dan bukan kedokteran di Universitas Lahore Pakistan. Hasil Penelitian menunjukkan bahwa mahasiswa kedokteran merupakan mahasiswa yang paling banyak mengonsumsi kafein tiap harinya yaitu $66 \%$. Selain itu, Liveina (2014) melakukan penelitian terkait pola konsumsi dan efek samping minuman mengandung kafein pada mahasiswa Program Studi Pendidikan Dokter (PSPD) Fakultas Kedokteran Universitas Udayana, dimana ditemukan sebesar $76,1 \%$ mahasiswa yang mengonsumsi kopi mengalami gangguan tidur berupa kesulitan tidur sebesar 50,5\%. Namun belum diteliti faktor-faktor seperti riwayat penyakit, kondisi lingkungan, konsumsi rokok dan alkohol, stress psikologi, obesitas dan aktivitas fisik yang juga dapat mempengaruhi kualitas tidur.

Berdasarkan hasil penelitian tersebut, peneliti tertarik melakukan penelitian terkait faktor-faktor yang berhubungan dengan kualitas tidur mahasiswa yang mengonsumsi kopi di Fakultas Kedokteran Universitas Udayana.

\section{METODE PENELITIAN}


Penelitian ini merupakan penelitian analitik dengan pendekatan kuantitatif menggunakan rancangan cross-sectional, yang dilakukan di Fakultas Kedokteran Universitas Udayana selama bulan AprilJuni tahun 2020. Populasi target pada penelitian ini adalah seluruh mahasiswa Fakultas Kedokteran Universitas Udayana. Sedangkan populasi terjangkau pada penelitian ini adalah mahasiswa reguler Fakultas Kedokteran Universitas Udayana yang masih aktif pada masingmasing program studi. Kriteria inklusi pada penelitian ini yaitu mahasiswa regular aktif fakultas Kedokteran Universitas Udayana yang gemar meminum kopi sekurang-kurangnya 1 gelas/hari.

Teknik pengambilan sampel menggunakan metode systematic random sampling dengan jumlah sampel yaitu 118 responden. Pengumpulan data dilakukan dengan wawancara menggunakan kuesioner PSQI (Pittsburgh Sleep Quality Index) untuk mengukur kualitas tidur responden, kuisioner SST (The Subjective Symptoms Test) yang digunakan untuk mengukur kelelahan secara subjektif serta kuisioner GPAQ (Global Physical Activity Questionnaire) untuk mengukur tingkat aktivitas fisik responden.

Data dianalisis secara univariabel dengan mendeskripsikan distribusi frekuensi dan proporsi masing-masing variabel. Analisis bivariabel menggunakan uji regresi logistic sederhana dengan tingkat kepercayaan $\quad 95 \% \quad(\alpha=0,05) \quad$ untuk mengetahui hubungan variabel bebas dengan variabel tergantung. Serta analisis multivariabel dilakukan dengan uji Binary logistic regression dengan melakukan seleksi terhadap variabel yang memiliki nilai $\mathrm{p}<0,2$ pada analisis bivariabel untuk mengetahui variabel bebas yang paling berpengaruh terhadap variabel tergantung.

\section{HASIL}

\section{Karakteristik Responden}

Tabel 1, menunjukan bahwa sebanyak 26 orang $(22,03 \%)$ responden merupakan laki-laki dan 92 responden lainnya (77,97\%) merupakan perempuan. Sebagian besar responden berasal dari mahasiswa semester 6 yakni 35 orang $(29,66 \%)$ dan lainnya yaitu semester 2 sebanyak 33 orang $(27,97 \%)$, semester 4 dan semester 8 sebanyak 25 orang $(21.19 \%)$.

\section{Tabel 1. Gambaran Karakteristik Responden}

\begin{tabular}{lcc}
\hline $\begin{array}{c}\text { Karakteristik } \\
\text { Responden }\end{array}$ & $\begin{array}{c}\text { Frekuensi } \\
\text { (n) }\end{array}$ & $\begin{array}{c}\text { Proporsi } \\
\text { (\%) }\end{array}$ \\
\hline Jenis & & \\
Kelamin & & \\
$\quad$ Laki-laki & 26 & 22,03 \\
$\quad$ Perempuan & 92 & 77,97 \\
\hline Semester & & \\
2 & 33 & 27,97 \\
4 & 25 & 21,19 \\
6 & 35 & 29,66 \\
8 & 25 & 21,19 \\
\hline
\end{tabular}

2. Faktor-Faktor yang Memengaruhi Kualitas Tidur

Pada Tabel 2, tingkat konsumsi minuman kopi responden terbanyak pada tingkat konsumsi normal sebesar 61,86\%. Responden sebagian besar menambahkan gula pada minuman kopi yang dikonsumsi yakni sebesar $86,44 \%$. 
Tabel 2. Gambaran Faktor-Faktor yang Memengaruhi Kualitas Tidur

\begin{tabular}{|c|c|c|}
\hline Variabel & Frekuensi & Persen $(\%)$ \\
\hline \multicolumn{3}{|l|}{ Konsumsi Kopi } \\
\hline Normal & 73 & 61,86 \\
\hline Menengah & 33 & 27,96 \\
\hline Tinggi & 12 & 10,16 \\
\hline \multicolumn{3}{|l|}{ Penggunaan Gula } \\
\hline Ya & 102 & 86,44 \\
\hline Tidak & 16 & 13,56 \\
\hline \multicolumn{3}{|l|}{ Jenis Minuman Kopi } \\
\hline Espresso & 13 & 11,02 \\
\hline Americano & 13 & 11,02 \\
\hline Cappucino & 53 & 44,92 \\
\hline Latte & 39 & 33,05 \\
\hline \multicolumn{3}{|l|}{ Konsumsi Minuman } \\
\hline \multicolumn{3}{|l|}{ Kafein Lainnya } \\
\hline $\mathrm{Ya}$ & 52 & 44,07 \\
\hline Tidak & 66 & 55,93 \\
\hline \multicolumn{3}{|l|}{ Konsumsi Rokok } \\
\hline $\mathrm{Ya}$ & 2 & 1,69 \\
\hline Tidak & 116 & 98,31 \\
\hline \multicolumn{3}{|l|}{ Konsumsi Alkohol } \\
\hline $\mathrm{Ya}$ & 8 & 6,78 \\
\hline Tidak & 110 & 93,22 \\
\hline \multicolumn{3}{|l|}{ Kondisi Lingkungan } \\
\hline \multicolumn{3}{|l|}{ (Cahaya) } \\
\hline Tidur dengan Lampu & 69 & 58,47 \\
\hline Tidur tanpa Lampu & 49 & 41,53 \\
\hline \multicolumn{3}{|l|}{ Indeks Masa Tubuh } \\
\hline Kurus & 34 & 28,81 \\
\hline Normal & 36 & 30,5 \\
\hline Gemuk & 48 & 40,67 \\
\hline \multicolumn{3}{|l|}{ Riwayat Penyakit } \\
\hline $\mathrm{Ya}$ & 49 & 41,53 \\
\hline Tidak & 69 & 58,47 \\
\hline \multicolumn{3}{|l|}{ Kelelahan Psikis } \\
\hline Tidak Kelelahan & 43 & 36,44 \\
\hline Kelelahan Ringan & 29 & 24,57 \\
\hline Kelelahan Sedang & 30 & 25,42 \\
\hline Kelelahan Berat & 16 & 13,55 \\
\hline \multicolumn{3}{|l|}{ Aktivitas Fisik } \\
\hline Rendah & 35 & 29,66 \\
\hline Sedang & 55 & 46,61 \\
\hline Tinggi & 28 & 23,72 \\
\hline
\end{tabular}

*Email Korespondensi: noviardiani2502@gmail.com 
Responden paling banyak mengonsumsi minuman kopi berjenis Cappucino yakni 53 orang (44,92\%), Latte yakni 39 orang $(33,05 \%)$, Espresso dan Americano yakni masing-masing 13 orang $(11,02 \%)$. Selain minuman kopi, responden sebanyak 52 orang $(44,07 \%)$ juga mengonsumsi minuman berkafein lainnya seperti minuman bersoda, teh, serta minuman berenergi.

Responden diketahui sebagian besar tidak mengonsumsi rokok $(98,31 \%)$ dan alkohol (93,22\%). Sebanyak 69 responden $(58,47 \%)$ tidur dengan menggunakan lampu, sedangkan 49 responden (41,53\%) tidur tanpa menggunakan lampu. Responden diketahui memiliki riwayat penyakit seperti migrain, vertigo, asma, gastritis, sinusitis, serta penyakit radang paru-paru yakni sebanyak 49 orang (41,53\%). Tingkat kelelahan psikis responden diantaranya 43 orang $(36,44 \%)$ tidak mengalami kelelahan, 29 orang $(24,57 \%)$ mengalami kelelahan ringan, 30 orang $(25,42 \%)$ mengalami kelelahan sedang, serta 16 orang $(13,55 \%)$ mengalami kelelahan berat. Responden diketahui lebih banyak melakukan aktivitas sedang yakni sebanyak 55 orang $(46,61 \%)$, aktivitas rendah sebanyak 35 orang $(29,66 \%)$, serta aktivitas tinggi sebanyak 28 orang $(23,72 \%)$.

3. Kualitas Tidur Mahasiswa yang Mengonsumsi Kopi di Fakultas Kedokteran Universitas Udayana

Berdasarkan hasil analisis pada Tabel 3, diketahui bahwa proporsi responden yang memiliki kualitas tidur yang baik yakni $49,15 \%$, sedangkan proporsi responden yang memiliki kualitas tidur buruk yakni sebesar $50,85 \%$.

Tabel 3. Gambaran Kualitas Tidur Mahasiswa Fakultas Kedokteran Universitas Udayana

\begin{tabular}{ccc}
\hline $\begin{array}{c}\text { Kualitas } \\
\text { Tidur } \\
\text { Mahasiwa }\end{array}$ & $\begin{array}{c}\text { Frekuensi } \\
\text { (n) }\end{array}$ & $\begin{array}{c}\text { Proporsi } \\
\text { (\%) }\end{array}$ \\
\hline Baik & 58 & 49,15 \\
Buruk & 60 & 50,85 \\
\hline
\end{tabular}

\section{Hubungan Karakteristik Responden dengan Kualitas Tidur}

Tabel 4. Distribusi Frekuensi Kualitas Tidur Berdasarkan Karakteristik Responden

\begin{tabular}{cccccc}
\hline \multirow{2}{*}{$\begin{array}{c}\text { Karakteristik } \\
\text { Responden }\end{array}$} & $\begin{array}{c}\text { Buruk } \\
(\mathbf{n = 6 0 )}\end{array}$ & $\begin{array}{c}\text { Baik } \\
(\mathbf{n = 5 8 )}\end{array}$ & Total & $\mathbf{9 5 \%} \mathbf{C I}$ & $\mathbf{p}$ \\
\cline { 2 - 5 } & & & $0,26-1,55$ & 0,32 \\
Jenis Kelamin & & & \\
$\quad$ Laki-laki & $11(42,31 \%)$ & $15(57,69 \%)$ & $26(100 \%)$ & & \\
Perempuan & $49(53.26 \%)$ & $43(46.74 \%)$ & $92(100 \%)$ & & \\
Semester & & & & $0,75-1,44$ & \\
2 & $19(57,58 \%)$ & $14(42,42 \%)$ & $33(100 \%)$ & & \\
4 & $13(52 \%)$ & $12(48 \%)$ & $25(100 \%)$ & & \\
6 & $12(34,29 \%)$ & $23(65,71 \%)$ & $35(100 \%)$ & & \\
8 & $16(64 \%)$ & $9(36 \%)$ & $25(100 \%)$ & & \\
\hline
\end{tabular}

*Email Korespondensi: noviardiani2502@gmail.com 
Berdasarkan hasil tabulasi silang pada Tabel 4, ditemukan perbedaan proporsi pada responden dengan kualitas tidur buruk dimana responden perempuan lebih banyak (53,26\%) mengalami kualitas tidur yang buruk dibandingkan dengan laki-laki (42,31\%). Berdasarkan tingkat semester, diketahui proporsi kualitas tidur buruk terdapat pada responden dengan tingkat semester 8 (64\%) dan semester 2 (57,58\%) Namun, sesuai dengan Tabel 5 dari dua variabel yaitu jenis kelamin dan semester tidak ada yang memiliki hubungan bermakna dengan variabel tergantung pada penelitian ini yaitu kualitas tidur ( $p>0.05)$.

\section{Hubungan Faktor Konsumsi Kopi dengan Kualitas Tidur}

Tabel 5. Hubungan Faktor Konsumsi Kopi dengan Kualitas Tidur

\begin{tabular}{|c|c|c|c|c|c|}
\hline \multirow{2}{*}{$\begin{array}{c}\text { Faktor } \\
\text { Konsumsi } \\
\text { Minuman Kopi }\end{array}$} & \multicolumn{5}{|c|}{ Kualitas Tidur } \\
\hline & $\begin{array}{l}\text { Buruk } \\
(n=60)\end{array}$ & $\begin{array}{c}\text { Baik } \\
(n=58)\end{array}$ & Total & $95 \%$ CI & p \\
\hline Konsumsi Kopi & & & & $1,31-6,22$ & 0,007 \\
\hline Tinggi & $30(66,67 \%)$ & $15(33,33 \%)$ & $45(100 \%)$ & & \\
\hline Normal & $30(41,1 \%)$ & $43(58,9 \%)$ & $73(100 \%)$ & & \\
\hline $\begin{array}{l}\text { Penggunaan } \\
\text { Gula }\end{array}$ & & & & $1,841-39,43$ & 0,0009 \\
\hline Ya & $46(45,10 \%)$ & $56(54,9 \%)$ & $102(100 \%)$ & & \\
\hline Tidak & $14(87,5 \%)$ & $2(12,5 \%)$ & $16(100 \%)$ & & \\
\hline $\begin{array}{l}\text { Jenis Minuman } \\
\text { Kopi }\end{array}$ & & & & $1,44-3,68$ & 0,0001 \\
\hline Espresso & $12(92,31 \%)$ & $1(7,69 \%)$ & $13(100 \%)$ & & \\
\hline Americano & $10(76,92 \%)$ & $3(23,08 \%)$ & $13(100 \%)$ & & \\
\hline Cappucino & $23(43,40 \%)$ & $30(56,60 \%)$ & $53(100 \%)$ & & \\
\hline Latte & $15(38,46 \%)$ & $24(61,54 \%)$ & $39(100 \%)$ & & \\
\hline Konsumsi & & & & & \\
\hline Minuman & & & & $0,68-2,95$ & 0,34 \\
\hline Kafein Lainnya & & & & & \\
\hline $\mathrm{Ya}$ & $29(55,77 \%)$ & $23(44,23 \%)$ & $52(100 \%)$ & & \\
\hline Tidak & $31(46,97 \%)$ & $35(53,03 \%)$ & $66(100 \%)$ & & \\
\hline
\end{tabular}

Berdasarkan Tabel 5, pada tingkat konsumsi kopi, proporsi responden yang mengalami kualitas tidur buruk berada pada responden dengan tingkat konsumsi kopi yang tinggi (66,67\%). Responden yang tidak menggunakan gula $(87,5 \%)$ memiliki proporsi terbesar mengalami kualitas tidur yang buruk dibandingkan dengan responden yang menggunakan gula $(45,1 \%)$. Ditinjau berdasarkan jenis minuman kopi, 92,31\% responden yang mengalami kualitas tidur buruk mengonsumsi jenis minuman kopi espresso. Selain itu, responden yang mengonsumsi minuman berkafein lainnya memiliki proporsi yang lebih tinggi mengalami kualitas tidur yang buruk yakni 55,77\%.

Berdasarkan hasil analisis bivariabel, faktor tingkat konsumsi minuman kopi 
$(\mathrm{p}=0.008)$, penggunaan gula $(\mathrm{p}=0,0009)$ dan jenis minuman kopi $(0,0001)$ memiliki hubungan bermakna dengan kualitas tidur.

\section{Hubungan Faktor-Faktor lainnya dengan Kualitas Tidur}

Tabel 6. Hubungan Faktor- Faktor lainnya dengan Kualitas Tidur

\begin{tabular}{|c|c|c|c|c|c|}
\hline \multirow[b]{2}{*}{$\begin{array}{c}\text { Faktor-faktor } \\
\text { Pendukung }\end{array}$} & \multicolumn{5}{|c|}{ Kualitas Tidur } \\
\hline & $\begin{array}{l}\text { Buruk } \\
(n=60)\end{array}$ & $\begin{array}{l}\text { Baik } \\
(n=58)\end{array}$ & Total & $95 \% \mathrm{CI}$ & p \\
\hline Konsumsi & & & & & \\
\hline Rokok & & & & $0,059-15,81$ & 0,98 \\
\hline $\mathrm{Ya}$ & $1(50 \%)$ & $1(50 \%)$ & $2(100 \%)$ & & \\
\hline Tidak & $59(50,86 \%)$ & $57(49,14 \%)$ & $116(100 \%)$ & & \\
\hline Konsumsi & & & & $0,601-16,09$ & 0,14 \\
\hline $\begin{array}{c}\text { Alkohol } \\
Y_{a}\end{array}$ & $(750 /)$ & $2(25 \%)$ & $8(100 \%$ / & & \\
\hline $\begin{array}{l}\text { Ya } \\
\text { Tidak }\end{array}$ & $\begin{array}{c}0(15 \%) \\
54(49,09 \%)\end{array}$ & $\begin{array}{c}2(\angle 5 \%) \\
56(50,91 \%)\end{array}$ & $\begin{array}{c}8(100 \%) \\
110(100 \%)\end{array}$ & & \\
\hline $\begin{array}{l}\text { Kondisi } \\
\text { Lingkungan }\end{array}$ & & & & $1,093-4.89$ & 0,026 \\
\hline $\begin{array}{l}\text { Tidur dengan } \\
\text { Lampu }\end{array}$ & $41(59,42 \%)$ & $28(40,58 \%)$ & $69(100 \%)$ & & \\
\hline $\begin{array}{l}\text { Tidur tanpa } \\
\text { Lampu }\end{array}$ & $19(38,78 \%)$ & $30(61,22 \%)$ & $49(100 \%)$ & & \\
\hline $\begin{array}{l}\text { Indeks Masa } \\
\text { Tubuh }\end{array}$ & & & & $0,521-2,26$ & 0,82 \\
\hline Obesitas & $25(52,08 \%)$ & $23(47,92 \%)$ & $48(100 \%)$ & & \\
\hline Tidak Obesitas & $35(50 \%)$ & $35(50 \%)$ & $70(100 \%)$ & & \\
\hline $\begin{array}{l}\text { Riwayat } \\
\text { Penyakit }\end{array}$ & & & & $0,642-2,79$ & 0,43 \\
\hline $\mathrm{Ya}$ & $27(55.10 \%)$ & $22(44.9 \%)$ & $49(100 \%)$ & & \\
\hline Tidak & $33(47.83)$ & $36(52.17)$ & $69(100 \%)$ & & \\
\hline $\begin{array}{l}\text { Kelelahan } \\
\text { Psikis }\end{array}$ & & & & $1,28-6,101$ & 0,0082 \\
\hline Kelelahan & $45(60 \%)$ & $30(40 \%)$ & $75(100 \%)$ & & \\
\hline Tidak Kelelahan & $15(34,88 \%)$ & $28(65,12 \%)$ & $43(100 \%)$ & & \\
\hline Aktivitas Fisik & & & & $1,46-8,045$ & 0,0033 \\
\hline Rendah & $25(71,43 \%)$ & $10(28,57 \%)$ & $35(100 \%)$ & & \\
\hline Tinggi & $35(42,17 \%)$ & $48(49,15 \%)$ & $83(100 \%)$ & & \\
\hline
\end{tabular}

Berdasarkan Tabel 7, pada konsumsi rokok ditemukan sedikit perbedaan proporsi mengalami kualitas tidur buruk pada responden yang mengonsumsi (50\%) dan tidak mengonsumsi rokok (50,86\%) sedangkan pada konsumsi alkohol, diketahui responden yang mengonsumsi *Email Korespondensi: noviardiani2502@gmail.com alkohol (75\%) lebih banyak mengalami kualitas tidur yang buruk. Ditinjau berdasarkan kondisi lingkungan (cahaya), responden yang menggunakan lampu saat tidur lebih banyak mengalami kualitas tidur buruk $(59,42 \%)$ dibandingkan dengan responden yang tidak 
menggunakan lampu. Berdasarkan IMT, responden yang mengalami kualitas tidur buruk berada pada kategori obesitas (52,08\%). Dilihat berdasarkan riwayat penyakit, sebagian besar responden yang memiliki riwayat penyakit lebih banyak mengalami kualitas tidur yang buruk (55,1\%) dibandingkan dengan responden yang tidak memiliki riwayat penyakit. Dilihat pada tingkat kelelahan psikis, Sebagian besar responden yang mengalami kelelahan psikis lebih banyak memiliki kualitas tidur yang buruk yakni sebesar $60 \%$. Sedangkan pada tingkat aktivitas fisik, responden yang memiliki tingkat aktivitas rendah lebih banyak mengalami kualitas tidur yang buruk $(71,43 \%)$ dibandingkan dengan responden yang memiliki tingkat aktivitas tinggi. Berdasarkan analisis bivariabel, faktor kondisi lingkungan, kelelahan psikis, dan aktivitas fisik memiliki hubungan bermakna dengan kualitas tidur $(p \leq 0,05)$.

7. Analisis Multivariat Faktor-Faktor yang Berhubungan dengan Kualitas Tidur Mahasiswa yang Mengonsumsi Kopi di Fakultas Kedokteran Universitas Udayana Tabel 7. Model Akhir Analisis Multivariat

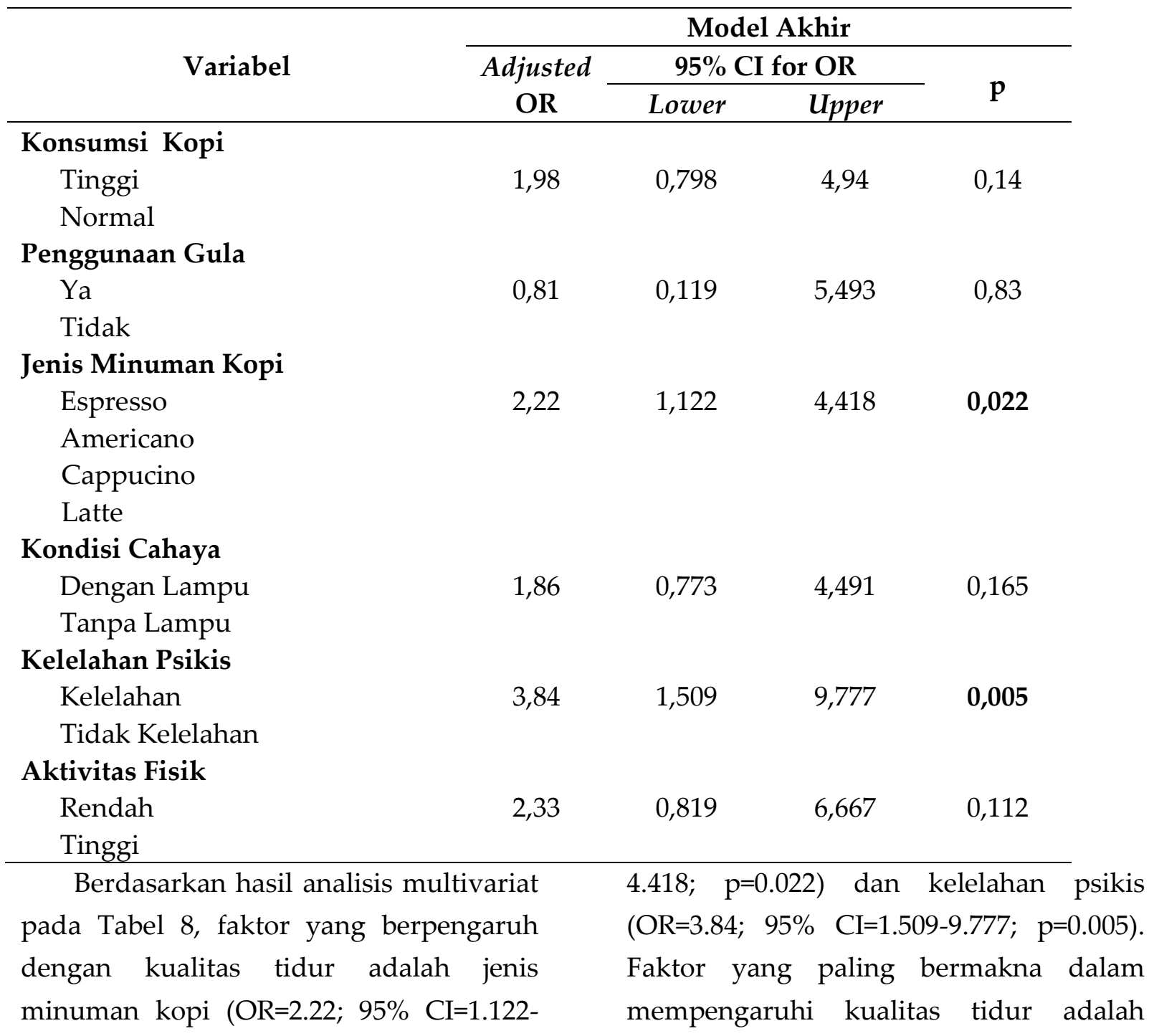


faktor kelelahan psikis. Berdasarkan nilai odds, responden yang mengalami kelelahan secara psikologis berisiko 3,84 kali lebih besar memiliki kualitas tidur

\section{DISKUSI}

Kualitas tidur pada mahasiswa yang mengonsumsi kopi di Fakultas Kedokteran Universitas Udayana didapatkan sebesar 49,15\% mengalami kualitas tidur yang baik dan 50,85\% mengalami kualitas tidur yang buruk. Hal ini sejalan dengan penelitian oleh Novianti \& Sundari (2019) yang melakukan penelitian terhadap mahasiswa kesehatan di Kota Denpasar. Hasil penelitian menunjukkan mahasiswa yang mengonsumsi kafein mengalami kualitas tidur yang buruk sebesar $77.3 \%$. Selain itu Penelitian oleh Preisegolaviciute, Leskauskas, \& Adomaitiene (2010) yang meneliti kualitas tidur antara mahasiswa kedokteran dengan mahasiswa ekonomi dan hukum. Hasil diperoleh bahwa mahasiswa kedokteran memiliki proporsi kualitas tidur buruk yang paling tinggi dibandingkan dengan mahasiswa ekonomi dan hukum yakni sebesar 59,4\%. Berdasarkan penelitian oleh Abdulghani, et al (2012) hasil menunjukkan bahwa siklus tidur pada mahasiswa kedokteran ditandai dengan kurangnya periode tidur, terlambatnya onset tidur serta adanya gangguan saat tidur.

Faktor yang memiliki pengaruh paling kuat dengan kualitas tidur yaitu faktor kelelahan psikis (OR=3.84; 95\% $\mathrm{CI}=1.509-9.777 ; \mathrm{p}=0.005)$. Responden yang yang buruk dibandingkan dengan responden yang tidak mengalami kelelahan secara psikologis.

mengalami kelelahan secara psikologis berisiko atau berpeluang 3.84 kali lebih

besar memiliki kualitas tidur yang buruk dibandingkan dengan responden yang tidak mengalami kelelahan secara psikologis. Hal ini dibuktikan dengan responden yang mengalami kelelahan psikis memiliki proporsi yang lebih tinggi mengalami kualitas tidur buruk yaitu $60 \%$. Hasil penelitian ini sejalan dengan penelitian oleh Rasyidah, Fitryasari, \& Wahyudi (2020) yang meneliti hubungan antara tingkat stress dan burnout syndrome dengan kualitas tidur pada mahasiswa profesi ners. Hasil menunjukkan bahwa faktor yang paling bermakna memengaruhi kualitas tidur yakni tingkat stress dengan nilai OR=1,076 (95\% $\mathrm{CI}=1,033-1,121)$ dimana faktor kelelahan psikis merupakan faktor dominan yang berhubungan dengan stress dan berpengaruh kuat terhadap kualitas tidur mahasiswa.

Penelitian serupa juga dilakukan oleh Saswati \& Maulani (2020). Hasil menunjukkan terdapat hubungan dengan signifikansi tinggi antara tingkat stress dengan kejadian insomnia pada mahasiswa dengan nilai $\mathrm{p}=0.000$. Hal ini disebabkan karena stressor yang dihadapi terus-menerus oleh mahasiswa dapat menyebabkan gangguan tidur yaitu insomnia serta sulitnya mempertahankan waktu tidur. 
Berdasarkan jenis kelamin, diketahui responden perempuan lebih banyak (53,26\%) mengalami kualitas tidur yang buruk dibandingkan dengan laki-laki (42,31\%). Hal ini disebabkan karena dalam menghadapi suatu permasalahan, perempuan lebih banyak menggunakan perasaannya dibandingkan dengan lakilaki sehingga perempuan lebih rentan terkena stress yang berkaitan degan kesulitan tidur yang dialami (Sutjiato \& Tucunan, 2015). Sedangkan pada tingkat semester, mahasiswa semester 8 (64\%) diketahui memiliki proporsi yang lebih tinggi mengalami kualitas tidur buruk dibandingkan dengan mahasiswa semester lainnya. Hal ini disebabkan karena mahasiswa semester 8 mengalami tingkat kecemasan yang lebih tinggi dikarenakan beban tugas akhir yang dialami sehingga mahasiswa mengalami stress serta rentan mengalami gangguan tidur (Wulandari, Hadiati, \& Sarjana,2017). Berdasarkan hasil analisis bivariat, jenis kelamin dan tingkat semester tidak memiliki hubungan bermakna dengan kualitas tidur ( $p>0.05)$. Hal ini disebabkan karena mahasiswa Fakultas Kedokteran Universitas Udayana berada pada rentang usia 16-22 tahun, sedangkan pada penelitian lain menyebutkan bahwa kualitas tidur buruk pada perempuan lebih banyak terjadi pada rentang usia 31-70 tahun (Viona, Putrini Sinaga, \& Handini, 2014). Selain itu, penelitian yang dilakukan Brick, Seely, \& Palermo (2010) juga menyatakan tidak terdapat hubungan antara masa studi dengan kualitas tidur dimana kualitas tidur buruk tidak hanya dialami oleh mahasiswa tingkat akhir namun banyak juga dialami oleh mahasiswa tingkat pertama dikarenakan masa transisi atau peralihan dari siswa menjadi mahasiswa.

Ditinjau berdasarkan tingkat konsumsi kopi, terdapat hubungan bermakna antara tingkat konsumsi minuman kopi dengan kualitas tidur mahasiswa $(p=0.007)$. Hal ini sesuai dengan penelitian yang dilakukan oleh Clark \& Landolt (2017) yang menyatakan bahwa konsumsi kopi dapat menghalangi sistem neuromodulator adenosin serta sistem reseptor yang berkaitan dengan siklus tidur dimana secara tidak langsung memengaruhi kualitas tidur seseorang. Berdasarkan rekomendasi Health Canada, konsumsi normal kafein berkisar $\leq 400 \mathrm{mg}$ per hari (Mitchell, Knight, Hockenberry, Teplansky, \& Hartman, 2014). Konsumsi kopi pada mahasiswa sebanyak 3 sampai 5 gelas per hari berhubungan dengan kebiasaan waktu tidur mahasiswa yakni $\leq$ 6 jam per malam (Chaudhary et al., 2016).

Berdasarkan penggunaan gula dalam minuman kopi, diketahui penggunaan gula memiliki hubungan bermakna dengan kualitas tidur mahasiswa. Hal ini sejalan dengan penelitian Alahmary et al (2019) yang meneliti hubungan antara penambahan asupan gula dengan kualitas tidur di kalangan mahasiswa Universitas Imam Abdulrahman Bin Faisal, Damman, Arab Saudi, hasil menunjukkan terdapat hubungan yang signifikan $(\mathrm{p}=0.014)$ antara konsumsi gula tambahan dan kualitas tidur pada mahasiswa dimana dampak negatif dari gula dapat mengakibatkan pertambahan berat badan 
dan mengganggu sistem metabolisme yang berkaitan dengan terganggunya periode tidur. Pada jenis minuman kopi, proporsi responden yang mengalami kualitas tidur yang buruk terdapat pada responden yang mengonsumsi minuman kopi dengan jenis espresso (92.31\%). Terdapat hubungan jenis minuman kopi dengan kualitas tidur dimana mahasiswa yang mengonsumsi kopi jenis espresso berpeluang 2.22 kali lebih besar mengalami kualitas tidur yang buruk dibandingkan dengan mahasiswa yang mengonsumsi jenis kopi lainnya. Berdasarkan Penelitian oleh Triantara (2017) menunjukan hasil pengukuran kadar kafein dalam jenis minuman kopi dimana jenis kopi espresso memiliki kadar kafein tertinggi yakni 182,4 mg/cangkir dibandingkan dengan jenis kopi cappuccino dan coffee latte yaitu berturutturut $54 \mathrm{mg}$ /cangkir dan 41,25 mg/cangkir.

Pada konsumsi minuman berkafein lainnya, tidak terdapat hubungan bermakna antara konsumsi minuman berkafein lainnya dengan kualitas tidur mahasiswa. Hal ini sejalan dengan penelitian Suwartika \& Cahyati (2015) dimana kebiasaan minum teh tidak memiliki hubungan yang signifikan terhadap kualitas tidur pada pasien gagal jantung $(p=0,933)$. Hal ini dikarenakan kadar kafein pada teh yang paling rendah dibandingkan dengan minuman berkafein lainnya seperti soda, kopi, maupun minuman berenergi.

Pada variabel konsumsi rokok dan alkohol, didapatkan hasil bahwa konsumsi rokok dan alkohol tidak memiliki hubungan bermakna dengan kualitas tidur. Hal ini berkaitan dengan proporsi mahasiswa yang hampir sebagian besar tidak mengonsumsi rokok dan alkohol. Penelitian lain juga mengatakan bahwa seseorang yang bukan perokok memiliki kualitas tidur yang lebih baik dibandingkan dengan seseorang yang merupakan perokok aktif (Dugas et al., 2017). Hasil serupa juga terdapat pada penelitian Ain, Indrawanto, \& Chandrawati (2016) terkait hubungan antara konsumsi kopi bersama rokok dengan kualitas tidur. Hasil menunjukkan bahwa tidak terdapat hubungan konsumsi kopi bersama rokok dengan kualitas tidur $(p=0.639)$. Selain itu, penelitian oleh Pavlovic \& Dindic (2014) terkait pengaruh konsumsi alkohol terhadap kualitas dan lama tidur mahasiswa tahun pertama studi doktoral di Fakultas Kedokteran Universitas NIS, Serbia. Hasil menunjukkan tidak terdapat hubungan yang signifikan antara lama tidur mahasiswa yang mengonsumsi alkohol dengan mereka yang tidak mengonsumsi alkohol $\quad(p=0,958)$ Hal tersebut dikarenakan efek farmakologis alkohol yaitu membantu seseorang untuk terlelap dikarenakan efek obat penenang atau efek sedasi dari alkohol tersebut.

Berdasarkan faktor kondisi lingkungan fisik, cahaya lampu diketahui memiliki hubungan bermakna dengan kualitas tidur $(p \leq 0,05)$. Hal ini disebabkan karena gelombang cahaya dapat masuk ke kelopak mata sehingga akan merangsang aktivitas otak untuk bekerja. Terhambatnya pembentukan hormone melatonin dapat memberikan perintah kepada tubuh manusia untuk 
mengabaikan tidur dan melakukan aktivitas lebih lama di malam hari sehingga berdampak pada gangguan kebutuhan tidur (Bronsard \& Bartolomei, 2013; Hubbard et al.,2013). Namun, hsil penelitian ini tidak sejalan dengan penelitian Sutrisno et al (2017). Hasil uji chi-square menunjukkan tidak terdapat perbedaan bermakna antara mahasiswa yang menggunakan lampu dan tidak menggunakan lampu dengan mayoritas subjek yang memiliki kualitas tidur yang buruk $(p=0.191)$. Hal ini dikarenakan respon tubuh seseorang yang telah beradaptasi dengan kondisi lingkungan fisik sekitarnya.

Ditinjau berdasarkan Indeks Massa Tubuh, proporsi responden yang mengalami kualitas tidur yang buruk paling besar berada pada kategori obesitas (52.08\%). Namun, tidak terdapat hubungan yang bermakna antara Indeks Masa Tubuh (IMT) dengan kualitas tidur pada responden $(p=0,82)$. Hal ini sesuai dengan penelitian Dewi et al (2014) yang meneliti hubungan Indeks Massa Tubuh (IMT) dan lingkar leher dengan kualitas tidur. Hasil menunjukkan tidak terdapat hubungan yang bermakna antara IMT dengan kualitas tidur ( $\mathrm{r}=0.24, \mathrm{p}=0.070)$. Faktor yang paling mempengaruhi kualitas tidur responden yaitu kondisi psikologis responden dengan signifikansi yang tinggi. Hasil penelitian lainnya oleh Anggoro K (2019) juga menunjukkan hasil yang tidak sesuai dengan hasil penelitian ini dimana obesitas tidak memiliki pengaruh yang bermakna pada kualitas tidur responden $(\mathrm{p}=0.483)$.
Pada determinan riwayat penyakit, diketahui bahwa $41.53 \%$ responden memiliki riwayat penyakit seperti migrain, vertigo, gastritis, sinusitis, asma, serta penyakit radang paru-paru. Berdasarkan analisis bivariabel, tidak terdapat hubungan bermakna antara riwayat penyakit responden dengan kualitas tidur. Hal ini disebabkan karena sebagian besar responden yang memiliki riwayat penyakit telah mampu mengatasi penyakit yang diderita secara mandiri. Hasil penelitian ini sejalan dengan penelitian yang dilakuan oleh Sabiq \& Fitriany (2016) dimana hasil menunjukkan tidak terdapat hubungan yang signifikan antara kualitas tidur terhadap peningkatan tekanan darah pada remaja di SMA Negeri 2 Lhokseumawe ( $p=0.231)$. Namun, hasil penelitian ini tidak sejalan dengan penelitian oleh Wicaksono et al (2012), hasil menunjukkan bahwa terdapat hubungan bermakna antara penyakit dengan kualitas tidur $(\mathrm{p}=0.022)$ dan koefisien korelasi menunjukkan terdapat hubungan yang lemah ( $\mathrm{r}=-0.324)$ yang bersifat negatif yakni semakin tidak adanya penyakit pada responden, maka semakin baik kualitas tidurnya.

Berdasarkan tingkat aktivitas fisik, hasil penelitian menunjukkan responden dengan aktivitas rendah (71.43\%) lebih banyak memiliki kualitas tidur yang buruk dibandingkan responden dengan aktivitas tinggi (42.17\%). Aktivitas fisik dapat menghasilkan hormon endorphin dan serotonin yang dapat mempermudah timbulnya rasa kantuk pada diri seseorang (Nurfadilah $\mathrm{H}$, Andono Ahmad, \& Julia, 2017). Selain itu, 
keletihan yang terjadi setelah melakukan aktivitas akan menimbulkan seseorang cepat tertidur dikarenakan siklus tidur tahap gelombang lambat diperpendek yang mengakibatkan seseorang lebih cepat masuk ke fase kedalaman tidur (Safaringga \& Herpandika, 2018). Berdasarkan hasil analisis bivariabel, terdapat hubungan bermakna antara aktivitas fisik dengan kualitas tidur responden $(p=0.0033)$. Hasil penelitian ini sejalan dengan penelitian Iqbal (2017) mengenai hubungan aktivitas fisik dengan kualitas tidur mahasiswa perantau di Yogyakarta. Hasil menunjukkan terdapat hubungan yang signifikan antara tingkat aktivitas fisik dengan kualitas tidur mahasiswa perantau $(\mathrm{p}=0.006)$, dimana mahasiswa yang aktif dalam beraktivitas memiliki peluang 4.136 kali lebih besar mendapatkan kualitas tidur yang baik dibandingkan mahasiswa yang tidak beraktivitas secara aktif.

\section{SIMPULAN}

Berdasarkan karakteristik responden, responden berjenis kelamin laki-laki sebesar $22.03 \%$ sedangkan perempuan sebesar $77.97 \%$. Ditinjau dari tingkat semester, responden pada tingkat semester 2 sebesar $27.97 \%$, semester 4 sebesar $21.19 \%$, semester 6 sebesar $29.66 \%$, dan semester 8 sebesar $21.19 \%$. Berdasarkan total skor PSQI, responden yang memiliki kualitas tidur baik sebesar $49.15 \%$ dan responden yang memiliki kualitas tidur buruk sebesar 50.85\%. Determinan faktor jenis minuman kopi memiliki hubungan yang bermakna dengan kualitas tidur, dimana mahasiswa yang mengonsumsi kopi jenis espresso

*Email Korespondensi: noviardiani2502@gmail.com berpeluang 2.22 kali lebih besar mengalami kualitas tidur yang buruk dibandingkan dengan mahasiswa yang mengonsumsi jenis kopi lainnya. Determinan faktor kelelahan psikis memiliki hubungan yang bermakna dengan kualitas tidur, dimana mahasiswa yang mengalami kelelahan secara psikologis berisiko atau berpeluang 3.84 kali lebih besar memiliki kualitas tidur yang buruk dibandingkan dengan mahasiswa yang tidak mengalami kelelahan secara psikologis.

\section{SARAN}

Bagi peneliti selanjutnya, diharapkan melakukan penelitian terkait dosis kafein pada jenis minuman kopi espresso, americano, cappuccino, serta latte sehingga diketahui jumlah kadar kafein tiap masing-masing jenis minuman kopi yang dikonsumsi mahasiswa serta meneliti faktor-faktor penyebab kelelahan psikis pada mahasiswa kedokteran yang kaitannya dengan kualitas tidur yang dialami mahasiswa.

\section{DAFTAR PUSTAKA}

Abdulghani, H. M., Alrowais, N. A., BinSaad, N. S., Al-Subaie, N. M., Haji, A. M. A., \& Alhaqwi, A. I. (2012). Sleep disorder among medical students: Relationship to their academic performance. Medical Teacher, 34(SUPPL. 1 ), 37-41. https://doi.org/10.3109/0142159X.2012 .656749

Ahmad, M., \& Tayyab, A. (2017). Knowledge and trends of caffeine consumption Among medical and non medical students of Lahore 
Pakistan, 12(2).

Ain, R. C., Indrawanto, I. S., \& Chandrawati, F. P. (2016). Hubungan Antara Konsumsi Konsumsi Kopi Bersama Rokok Dan Kualitas Tidur Pada Sopir Bus Di Terminal Arjosari Malang. Saintika Medika, 12(2), 107. https://doi.org/10.22219/sm.v12i2.527 4

Alahmary, S. A., Alduhaylib, S. A., Alkawii, H. A., Olwani, M. M., Shablan, R. A., Ayoub, H. M., ... Khattab, R. Y. (2019). Relationship Between Added Sugar Intake and Sleep Quality Among University Students: A Cross-sectional Study. American Journal of Lifestyle Medicine, $X X(X)$, 1-8. https://doi.org/10.1177/155982761987 0476

Alimul, A. (2012). Buku Ajar Kebutuhan Dasar Manusia. Surabaya: Health Books Publishing.

Anggoro K, Y. (2019). Pengaruh obesitas pada kualitas tidur mahasiswa Fakultas Kedokteran Universitas Udayana periode 2018, 10(3), 524529.

https://doi.org/10.15562/ism.v10i3.442

Brick, C. A., Seely, D. L., \& Palermo, T. M. (2010). Association between sleep hygiene and sleep quality in medical students. Behavioral Sleep Medicine, $8(2)$, 113-121. https://doi.org/10.1080/154020010036 22925

Bronsard, G., \& Bartolomei, F. (2013). Rhythms, rhythmicity and aggression. Journal of Physiology Paris, 107(4), 327-334. https://doi.org/10.1016/j.jphysparis.20 13.03.002

Chaudhary, N. S., Grandner, M. A., Jackson, N. J., \& Chakravorty, S. (2016). Caffeine consumption, insomnia, and sleep duration: Results from a nationally representative sample. Nutrition, 32(11-12), 11931199.

https://doi.org/10.1016/j.nut.2016.04.0 05

Christopher, D., Timothy, R., John, S., \& Thomas, R. (2013). Caffeine Effects on Sleep Taken 0,3, or 6 Hours before Going to Bed. Journal of Clinical Sleep Medicine, 9(11). https://doi.org/10.5664/jcsm.3170

Clark, I., \& Landolt, H. P. (2017). Coffee, caffeine, and sleep: A systematic review of epidemiological studies and randomized controlled trials. Sleep Medicine Reviews, 31, 70-78. https://doi.org/10.1016/j.smrv.2016.01 .006

Dewi, W., Arum, M., Kusumawati, R., \& Wiboworini, B. (2014). Hubungan Indeks Massa Tubuh ( IMT ) dan Lingkar Leher dengan Kualitas Tidur, 3(2), 242-249.

Dugas, E. N., Sylvestre, M. P., O'Loughlin, E. K., Brunet, J., Kakinami, L., Constantin, E., \& O'Loughlin, J. (2017). Nicotine dependence and sleep quality in young adults. Addictive Behaviors, 65, 154-160. https://doi.org/10.1016/j.addbeh.2016. 10.020

Hubbard, J., Ruppert, E., Gropp, C. M., \& Bourgin, P. (2013). Non-circadian direct effects of light on sleep and 
alertness: Lessons from transgenic mouse models. Sleep Medicine Reviews, 17(6), 445-452. https://doi.org/10.1016/j.smrv.2012.12 .004

Iqbal, M. D. (2017). Hubungan Aktivitas Fisik Dengan Kualitas Tidur Mahasiswa Perantau di Indonesia. Jurnal Pendidikan Jasmani Kesehatandan Rekreasi, 2(01), 227-234.

Liveina. (2014). Pola Konsumsi dan Efek Samping Minuman Mengandung Kafein Pada Mahasiswa Program Studi Pendidikan Dokter Fakultas Kedokteran Universitas Udayana, 3(4), 1.

M.Moran, A., \& Everhart, D. E. (2012). Adolescent Sleep: Review of Characteristics, Consequences, and Intervention. Journal of Sleep Disorders : Treatment \& Care, 01(02), 1-8. $\quad$ https://doi.org/10.4172/23259639.1000104

Mitchell, D. C., Knight, C. A., Hockenberry, J., Teplansky, R., \& Hartman, T. J. (2014). Beverage caffeine intakes in the U.S. Food and Chemical Toxicology, 63, 136-142. https://doi.org/10.1016/j.fct.2013.10.04 2

Novianti Tantri, I., \& Sundari, L. . R. (2019). Hubungan Antara Jenis Kelamin, Konsumsi Kafein, Tinggal Sendiri, dan Jam Mulai Tidur dengan Kualitas Tidur Buruk Mahasiswa di Kota Denpasar. Medika Udayana, 8(7), 9.

Nurfadilah H, S., Andono Ahmad, R., \& Julia, M. (2017). Aktivitas fisik dan screen based activity dengan pola tidur remaja di Wates. BKM Journal of Community Medicine and Public Health, 33(7), 343-350.

Pavlović, M., \& Đinđić, B. (2014). Alcohol Consumption Habits and Sleep Quality. Acta Medica Medianae, 53(2), 10-15.

https://doi.org/10.5633/amm.2014.020 2

Preišegolavičiute, E., Leskauskas, D., \& Adomaitiene, V. (2010). Associations of quality of sleep with lifestyle factors and profile of studies among Lithuanian students. Medicina, 46(7), 482-489.

https://doi.org/10.3390/medicina4607 0070

Rasyidah, Q. A., Fitryasari, R., \& Wahyudi, A. S. (2020). Hubungan Tingkat Stres dan Burnout Syndrome Dengan Kualitas Tidur Pada Mahasiswa Profesi Ners Fakultas Keperawatan Universitas Airlangga, 2(1).

https://doi.org/http://dx.doi.org/10.20 473/pnj.v1i1.19209

Sabiq, A., \& Fitriany, J. (2016). Tekanan Darah Pada Remaja Di Sekolah Menegah Atas ( Sma ) Negeri 2 Lhokseumawe, 1-15.

Safaringga, E., \& Herpandika, R. P. (2018). Hubungan antara Kebugaran Jasmani dengan Kualitas Tidur. Jurnal SPORTIF: Jurnal Penelitian Pembelajaran, 4(2), 235. https://doi.org/10.29407/js_unpgri.v4i 2.12467

Sarfriyanda, J., Karim, D., \& Pristiana D, A. (2015). Hubungan Antara Kualitas Tidur dan Kuantitas Tidur Dengan 
Prestasi Belajar Mahasiswa. Journal of Medical, 2(37), $1-31$. https://doi.org/10.12816/0013114

Saswati, N., \& Maulani. (2020). Hubungan Tingkat Stress Dengan Kejadian Insomnia Pada Mahasiswa Prodi Keperawatan. Malahayati Nursing Journal, 2(2), 336-343.

Sutjiato, M., \& Tucunan, G. D. K. a a T. (2015). Hubungan Faktor Internal dan Eksternal dengan Tingkat Stress pada Mahasiswa Fakultas Kedokteran Universitas Sam Ratulangi Manado. Jikmu, 5(1), 30-42. Sutrisno, R., Faisal, F., \& Huda, F. (2017). Perbandingan Kualitas Tidur Mahasiswa Fakultas Kedokteran Universitas Padjadjaran yang Menggunakan dan Tidak Menggunakan Cahaya Lampu saat Tidur. Jurnal Sistem Kesehatan, 3(2), 73-79.

https://doi.org/10.24198/jsk.v3i2.1500 6

Suwartika, I., \& Cahyati, P. (2015). Analisis Faktor Yang Berpengaruh Terhadap Kualitas Tidur Pasien Gagal Jantung Di RSUD Kota Tasikmalaya. Jurnal Skolastik Keperawatan, 1(01), 7-13.

Triantara, A. N. (2017). Perbedaan Kualitas Tidur Setelah Mengonsumsi Berbagai Jenis Minuman Kopi Pada Usia Dewasa. Journal of Nutrition
College, 6(4).

Viona, Putrini Sinaga, J., \& Handini, M. (2014). Hubungan Antara Karakteristik Mahasiswa Dengan Kualitas Tidur Pada Mahasiswa Program Studi Pendidikan Dokter Fakultas Kedokteran Universitas Tanjungpura. Jurnal Mahasiswa Fakultas Kedokteran Untan, 1(1), 69-73. https://doi.org/10.11113/jt.v56.60

Wicaksono, D. W., Yusuf, A., \& Widyawati, I. Y. (2012). Analisis Faktor Dominan yang Berhubungan Dengan Kualitas Tidur Pada Mahasiswa Fakultas Keperawatan Universitas Airlangga. Nursing Journal, 1(1), 46-58. https://doi.org/http://dx.doi.org/10.20 473/fmnj.v1i1.12131

Wulandari, F., Hadiati, T., \& Sarjana, W. (2017). Hubungan Antara Tingkat Stres Dengan Tingkat Insomnia Mahasiswa/I Angkatan 2012/2013 Program Studi Pendidikan Dokter Fakultas Kedokteran Universitas Diponegoro. Jurnal Kedokteran Diponegoro, 6(2), 549-557. 